\title{
Graft-Incompatibility in Horticultural Crops
}

\author{
Komal Dogra*, Kiran Kour, Rakesh Kumar, Parshant Bakshi and Vijay Kumar \\ Division of Fruit Science, Sher-e-Kashmir University of Agricultural Sciences and Technology \\ of Jammu, Main Campus, Chatha, Jammu-180009, India \\ *Corresponding author
}

\begin{tabular}{|l|}
\hline K e y w o r d s \\
Graft compatibility, \\
Graft \\
incompatibility, \\
Fruit crops
\end{tabular}

\section{A B S T R A C T}

The mechanism of graft incompatibility is not yet fully understood and many reports focus on this problem in order to understand the mechanisms of graft development. Graft incompatibility is reported due to the Structural or Anatomical reasons, physiological and biochemical reasons, nutritional deficiency and presence of viruses at an early phase in response to grafting, as well as the consequences of these events on the future graft response. All these abnormalities result in mechanical weakening of the union, which may manifest the first year after grafting or may appear several years later, leading to major economic losses. Successful union of stock/scion involves lining up of vascular cambiums, subsequent wound healing response, callus bridge formation, wound repair xylem and phloem occur in the callus bridge just prior to initial cambium formation, the vascular cambium is completed across the callus bridge and is forming secondary xylem and phloem. The phloem mobile proteins have been reported that cross the graft interface when graft bridging is established and is functional. Commercial fruit trees are usually formed by the combination of a rootstock and a scion to broaden the adaptability of scion cultivars to soil and climatic conditions, facilitate agricultural management, and/or increase productivity. Graft incompatibility is a problem in cherry, almond, and apricot than in peach or plum, pear or quince. In general, closely related cultivars species unite readily and grow as a composite plant and that of unrelated plant do not. Even sometimes stock/scion of unrelated species unites initially and develops symptoms of incompatibility later and die eventually. An early and accurate prediction of graft incompatibility has great importance because incompatible combinations could be avoided while compatible ones could be selected. The complexity of incompatibility and the mechanism behind the reactions have been investigated in several ways. Moreover, research is needed to fully understand the mechanism of graft incompatibility, particularly in woody plants. This knowledge is essential to develop molecular markers useful in rootstock breeding programs.

\section{Introduction}

Plant propagation refers to multiplication of an individual plant or group of plants, which have specific value to mankind. In other words, perpetuation of plants is called propagation. It is broadly grouped into two. 1. Sexual Propagation. 2. Asexual Propagation. Sexual propagation refers to multiplication of plants by seed. It has certain limitations such owing 
to genetic segregation in heterozygous plants, seedling trees are not uniform in their growth, yielding capacity and fruit quality compared to asexually propagated plants. Seedling trees are not usually true to type and show variation. Sexually propagated plants have long juvenile period, seeds loose viability within a short period e.g., citrus, mango, jack fruit, papaya, jamun etc. Asexual propagation is reproduction by means of vegetative parts of the plant. In asexual propagation there is no change in the genetic makeup of the plants. Grafting is a method of asexual propagation. Grafting is mainly done to obtain true-to-type plants. Grafting is defined as the uniting of two or more pieces of living plant tissues so that they grow as a single plant Graft compatibility is the ability of two different plants grafted together, to produce a successful union and continue to develop into one composite plant. Graft incompatibility is the inability or failure of rootstock and scion grafted together to produce a successful graft union. Graft failure can be caused by anatomical mismatching, poor craftsmanship, adverse environmental conditions, disease, and graft incompatibility. Graft incompatibility occurs because of: (1) adverse physiological responses between the grafting partners, (2) virus or phyto-plasma transmission, and (3) anatomical abnormalities of vascular tissue in the callus bridge. The distinction between a compatible and incompatible graft union is not always clear cut.

Modern fruit growing makes extensive use of selected rootstocks for wide variety of purposes, including vigor control, which enable high density planting, disease and pest tolerance/resistance, resistance/tolerance to abiotic stresses like hypoxia, reduce the time to fruiting, increase profit returns, improve fruit quality and yield, improve cold hardiness, cope with the chilling requirement of scion, and/or to alleviate certain syndromes like replant complex. In addition, modern cultural methods are evolving towards the use of clonal rootstocks as opposed to seedling rootstocks that were commonly used in past. The above mentioned role of rootstocks is the result of active rootstock/scion interactions, most of which are the result of complex processes occurring at the rootstock/ scion union, most of which are poorly understood (Gainza et al., 2015). The most important interactions are compatibility or incompatibility between rootstocks and scion. There is rootstock/scion compatibility when given combination is able to form a solid and durable graft union. Compatibility is difficult to predict, but there is general consensus that a degree of taxonomic relatedness should exist in order for a particular stock/scion combination to be compatible. The greater the taxonomic distance between stock and scion the smaller the chances of forming a successful graft union. This means that the theoretical success of a particular graft union combination is intraclonal>interclonal $>$ intraspecific > interspecific >intrageneric> intergeneric >intrafamilial (Andrews and Maruez, 1993). Also, different taxa may differ in the degree of relatedness required for the formation of successful graft unions (Rom and Carlson, 1987). Therefore, compatibility is very specific, meaning that a particular rootstock is generally not compatible with all commercial varieties of a given species.

According to Okie (1987); (Zarrouk et al., 2006) in modern horticulture this is a limiting factor, particularly in peach and cherry where there is lack of commercial rootstocks having broad compatibility. Rootstock/scion graft compatibility is, therefore, a critical issue for orchard performance and longevity. To remain functional, the stock/scion union should unify intimately, providing a viable system for uptake and translocation of minerals, water, assimilates and hormones throughout the entire lifespan of the plant (Martinez-Ballesta 
et al., 2010; Gregory et al., 2013 and Koepke and Dhingra, 2013). In contrast, graft incompatibility leads to unhealthy trees, breakage at the graft union, premature death or failure of the graft combination and incapacity to form a strong and lasting functional union (Zarrouk et al., 2006). In Prunus species, incompatibility is a problem in cherry, almond and, especially, apricot, than in peach or plum (Table 1) (Lang and Ophardt, 2000).

Two types of incompatibility are recognized: so called translocated graft incompatibility and localized graft incompatibility. Tis former is usually expressed during the first year after grafting as growth cessation, defoliation, and leaf discoloration (Herrero, 1951 and Mosse, 1962). In peach/plum combinations, this form of incompatibility has been associated with both biochemical and functional alterations at the graft interface, inducing a carbohydrate blockage at the scion, above the graft union (Moing et al., 1990). In later case, incompatibility symptoms occur where the presence of some biochemical alterations across the graft union may lead to a slight and delayed incompatibility, it has been described in cherry and peach/plum combinations (Treutter and Feucht., 1991; Salesses and Bonnet, 1992). This type of incompatibility is characterized by anatomical irregularities at the stock/scion union interface, with breaks in vascular and cambial continuity patterns and poor vascular connections that induce mechanical weakness in the union (Koepke and Dhingra, 2013) that may break out after years of orchard establishment, leading to major economic losses.

This review provides a summary of new advances in studies on the mechanism of graft incompatibility and knowledge currently available on the metabolic responses during the formation and establishment of the stock/scion graft union in order to help the effort for identify future metabolic markers to be used in breeding programs.

\section{Formation of graft union}

A number of detailed studies have been made of graft union formation, with woody and herbaceous plants. Just as de novo meristems are necessary for adventitious bud and root formation, a de novo formed meri-stematic area must develop between the scion and rootstock if successful graft union formation is to occur. The parts of the graft that are originally prepared and placed close contact do not themselves move about or grow together. Rather the union is accomplished entirely by cells that develop after the actual grafting operation has been made. The graft union is initially formed by rapidly dividing callus cells, originating from scion and rootstock, which later differentiate to form the vascular cambium and the associated vascular system. The development of a compatible graft is typically comprised of three major events: adhesion of the rootstock and scion, proliferation of callus cells at the graft interface or callus bridge; and vascular differentiation across the graft interface. According to Weatherhead (1986), the formation of callus tissue at graft interface is the first response to grafting. Whereas it has been found that grafting failure can be characterized by lack of callus formation at the graft interface. Other studies have revealed that the new callus formed is a passive event that occurs in compatible and incompatible grafts and common response to wounding.The sequence of structural events occurring during the healing of graft union in woody and herbaceous plants has been reviewed by several authors (Moing and Carde, 1988; Tiedemann, 1989; Hartmann et al., 2002; Pina and Errea., 2005) but recently (Yin et al., 2012) identified six major events: (i) Woundinduced response, (ii) cleanup of cell debris, (iii) cellular communication, (iv) vascular reconnection. According to (Yin et al., 2012) some mRNA signals change just 24 hours after grafting, and 48 hours after grafting auxins increase at the union and stimulate cell 
division and differentiation. On third day, transport was already functioning across the graft union. This is an indication that new xylem and phloem formation follows the same pattern described by Dengler (2001) in normal shoots and roots.

As shown in figure Stage 1. Lining up of vascular cambium scion and stock. Stage 2. Sub sequent wound healing, Stage 3. Callus bridge formation. Stage 4. Wound repair xylem and phloem occurs in the callus bridge just priorto initial cambium formation. Stage 5. The vascular cambium is completed across the callus bridge and forming secondary xylem and phloem.

Plasmodesmata are diverse and highly dynamic structures that offer a unique pathway for symplastic cell communication and constitute a potential pathway among cells in the graft bridge. According to Lucas et al., 1993 and Schulz, 1999, studies on the mechanism of plasmodesmata have shown their important role in the mechanism of cellular communication being a subject to discussion the occurrence of symplastic connection in grafts for a long time. As Jefree and Yeoman (1983) defined, when callus cells come into contact, the cell walls undergo dissolution, holes in the cell wall appears, plasmalemma contact and plasmodesmata form. The mechanism of plasmodesmata formation has shown prominent differences in the development of interspecific plasmodesmata between graft partners suggesting that cell recognition and functional co-ordination may be involved in graft formation (Kollmann and Glockmann, 1985 and Kollmann et al., 1985). According to Kollmann et al., (1985), the insufficient coordination between adjacent cells lead to the formation of mismatching, half plasmodesmata through the cell wall only in the cell partner. In graft interfaces of incompatible heterografts, discontinuous and half plasmodesmata have been observed in the graft unions between different types of cell markers in order to identify the graft interface. It indicate that plasmodesmata may contribute to graft failure due to misalignment of graft partners, although they may not be unique to graft incompatibility.

According to Errea et al., (1994) found that when apricot (Prunus armeniaca) grafted on plum, resulted in the formation of new vascular connections both compatible and incompatible combinations. The transport of disodium fluorescein across the graft union confirms the communication and functionality of these connections since fluorescence can be seen in both the partners of graft. In these combinations, the difference between compatible and incompatible grafts lies in the presence of a portion of the callus tissue in incompatible grafts that cannot differentiate into cambium and vascular tissue, resulting in the existence of wide areas at the union similar to undifferentiated callus cells. This lack of cambial activity in some areas of the graft union could affect the activity of the new xylem and phloem formed, causing discontinuities in the cambium. According to Hartmann et al., (2002) Graft compatibilityincompatibility in fruit crops: Mechanism and determination techniques and the vascular connection, producing a mechanically weak union.

\section{Anatomical Investigations}

Anatomical developments leading to the establishment of a graft union in herbaceous and perennial plants of both momo- and dicotyledonous species have been investigated from various points of view. Many of these investigations are listed by Roberts. (1949), the early processes of graft union, which follow a similar pattern in various woody plants, have been investigated in Citrus (Mendel, 1936), peaches (Scaramuzzi, 1952), 
pears on quince (Thiel, 1954), poplars (Braun, 1958) and apples (Mosse and Labern, 1960). The normal sequence of events is as follows. Cells damaged in the grafting operation turn brown and die. Within 24 hours meri-stematic activity starts in the underlying cells and the formation of wound callus begins. This is derived from exposed surfaces of the rootstock, i.e. the undifferentiated xylem and internal surfaces of the bark flap, and to a lesser extent, from cambium and cortical tissues of the bud shield. The callus of stock and scion meet but remain demarcated by a more or less continuous brown line consisting of dead and crushed cell remains. In citrus and plums wound gum may develop along the line which is gradually resorbed. According to Thiel (1954), the resportion of this layer occurs more quickly and thoroughly in compatible than in incompatible unions of pear on quince. The observation on the rate and extent of found in the early processes of union of the tissues has been established, there have been no detailed anatomical investigation to show at what point the development stops.

\section{The role of hormones}

According to Sorce et al., (2002), Aloni et al., (2010), Koepke and Dhingra (2013) observed that endogenous plant hormones are thought to be involved in regulating the complex relationships between rootstock and Scion. Aloni, 1995 found that in vascular regeneration experiments, when auxins were applied exogenously to stem segments, low concentrations $(0.1 \%$ w/w) of indole-3-acetic acid (IAA) stimulated phloem differentiation, whereas higher levels $(1.0 \%$. w/w) induced xylem differentiation. Likewise, in grafting experiments, an important group of substance involved in development of compatible graft unions is the auxins released from the vascular strands of the stock and the scion, which induce the differentiation of vascular tissues, thus functioning as morphogenic substances
(Aloni, 1987; Mattsson et al., 2003). Shimomura and Fujihara, 1977 observed translocation from the scion to the stock were found to accelerate the development of a successful graft union in Cactus.

Aloni et al., (2008; 2010) showed that, in grafted Cucurbita, exogenous application of high concentrations (> $\left.10^{-7} \mathrm{M}\right)$ of 1naphthalene acetic acid (NAA), a synthetic auxin, to the root caused inhibition of root growth. Root growth of incompatible grafts was more affected than that of compatible ones. NAA was also applied directly to the roots of hydroponically grown grafted plants, which caused root decay in incompatible grafts but less harm in compatible ones.

The involvement of auxin in the incompatibility mechanism emerged from three additional observations: (i) endogenous IAA analysis revealed that the roots and stems of incompatible combinations contained higher IAA concentrations than same tissues of compatible ones: (ii) application of the auxin transport inhibitor, 2,3,5-triiodobenzoic acid, to the stems of grafted plants negated root degradation in incompatible combinations, whereas it had only slight effect on compatible graft combinations; and (iii) root and shoot development of incompatible grafts was normal after blocking basipetal IAA transport by partial stem gridling (Aloni et al., 2008). These results support the hypothesis that auxin produced in the scion is translocated downwards to the root after the graft connection is established, where, after reaching a threshold concentration, auxin triggers degradative processes causing root decay (Aloni, 2010; Aloni et al., 2010).

Errea et al., (1994), Salvatierra et al., (1999) found that in $P$. tomentosa (stock) and $P$. armeniaca (scion), a differential accumulation of flavon-3-ols occurring during early stages of grafting was related to problems in the 
differentiation of callus and catechin, a flavonol, is known to be a protective agent against IAA oxidation (Lee and Oda, 2003; Parham and Kaustinen, 1977; Salvatierra et al., 1999) and can modulate the IAA oxidase level (Salvatierra et al., 1999). Moreover, the synthesis of prunasin, another flavon-3-ol, can determine incompatibility in Prunus (Moing and Carde, 1988; Stafford, 1990) and be stimulated by ABA and GA (Treutter and Feucht, 1991; Salvatierra et al., 1999; Aloni et al., 2010). Similarly, in phloem tissues of heterografts, the increase in prunin above the union indicates that the rootstock influences the normal gradient of phenolic compounds (Salvatierra et al., 1999). Feucht et al., (1988) also noticed that pruning caused less callus growth and inhibited xylogenesis and peroxidase activity. In xylem tissue, prunin and naringenin, which accumulated at the graft union of heterograft trees, could affect wound healing. Although less naringenin than prunin was found, this relatively small amount of the naringenine may still be enough to induce dysfunction at the interface between two cells (Errea et al., 1994). Naringenine was found to function as an inhibitor of the growth promoting activity of gibberellin while stimulating IAA oxidase (Feucht et al., 1988)

\section{The causes of breakage and the initiation of vascular discontinuity}

The detailed descriptions of Proebsting (1928), Bradford and Sitton (1929), Herrero (1951) and others, the immediate causes of breakage in temperate fruit trees are now well understood. After the initial establishment of vascular continuity, which may last for a length of time varying from under one year (Herrero, 1951) to ten years or more (Miller et al., 1957), some reaction occurs which causes a localized disorganization of the cambium at the point of union. As little as $1 \mathrm{~mm}$ above and below this point the cambium continues to function normally and thus the trunk on the either side of the union extends in girth, at the point of union no normal vascular tissue develops. The gap thus formed is filled in by proliferating ray tissue which does not lignify normally. As the process continues, the separate cambia of stock and scion extend laterally and eventually assume a horizontal position on either side of the gap in the vascular cylinder. The gap filled by proliferating ray cells is gradually widened by ingrowing tissues of the bark, which are derived from both stock and scion. Frequently a brown separation layer, similar to the primary separation layer that develops in the wound callus, is formed at union of the two tissues. Parts of separation layer become surrounded by phellogens which coalesce, and eventually a continuous dark brown cork layer forms horizontally across the bark at the point of union. Whilst disturbances in the bark are the probable cause of the stunted growth, excessive fruiting and sparse, yellow foliage, the mechanical weakness of the union is due to the absence of fibre and vessel connection. Instances can be cited (Eames and Cox., 1945; Hatton., 1936; Mosse., 1960) of apparently normal mature trees, not suspected of being incompatible until they suddenly broke at the union, and it is a surprising fact that in such trees water conduction appears to be impeded, although there is virtually no continuous vessel system across the union. The indications are that direct sieve tube connection is equally lacking, although (Buchloh,1958) considers that in young graft unions new sieve tube connections are rapidly established as older ones become functionless owing to incompatibility

The anatomical developments leading to breaks in vascular continuity have been extensively studied. Herrero (1951) investigated whether anatomical differences between stock and scion might be a cause of cambial discontinuity. He found that the proportion and size of xylem elements, 
distance between rays and width of uniseriateray initials of compatible varieties of plum and pear were no more similar to those of the rootstock than those of incompatible varieties. He noted that in pear /quince unions the reaction leading to breaks occurred quite suddenly and was connected with the necrosis of a layer of cells in the bark. In plums breaks usually developed more gradually, slowing down of cambial activity at the point of union being followed by the complete disorganization of this region. Mosse and Scaramuzzi (1956) concluded that pear/quinceunions necrosis was most prevalent in the two year old phloem and that it spread inwards along the rays until at times of low cambial continuity. They further observed that horticulturally compatible and incompatible pear varieties were likely to be quantitative rather than qualitative. On the basis of their anatomical studies both Herrero (1951) and Mosse and Scaramuzzi (1956) considered that the causes leading to necrosis and breaks in cambial continuity were biochemical rather than anatomical, were influenced by seasonal metabolic changes occurring in the tree. The success of patch grafting and double budding technique (Garner, 1948, 1953) in which the insertion of a very small intermediate, consisting of bark tissue only, is sufficient to overcome incompatibility, suggests that the condition is initiated by interactions between adjacent cells of stock and scion.

\section{The possibility of forecasting incompatibility from union structure}

An early and accurate forecast of graft combinations likely to prove incompatible is of economic importance, but attempts to forecast defective union structure are complicated by two factors: (1) the union structure of incompatible trees can be very variable, not only as between different positions in the same graft union and even at different times in corresponding positions; (2) the detailed examination necessitated by this variability of unions usually entails the destruction of the examined trees. A critical investigation therefore requires the examination of young trees on a sampling basis, and the subsequent observation of a comparable set of trees under field conditions. There have been few such investigations Herrero (1951) made an extensive study of one and two year old unions of sixteen plum and nine pear graft combinations whose subsequent field performance was observed by Mosse (1958, 1960), Lapins (1959) compared five different characters as an index of defective union structure in the two year old apricot trees and correlated the results with the known field performance of these graft combinations. Scaramuzzi (1957) examined the union structure of fifty pear varieties on clonal quince rootstock and found that in five year old trees size was determined more by varietal vigour than union structure

Compatibility of the union has been estimated in three ways: by measuring its resistance to the flow of water (Chang., 1937; Evans and Hilton, 1957); by measuring its resistance to forcible breakage (Chang, 1937; Garner, 1948; Randhawa and Upshall, 1949; Evans and Hilton, 1957; Lapins, 1959); and by microscopic and macroscopic examination of its anatomical structure (Garner, 1948; Herrero, 1951; Mosse, 1958, 1960; Lapins, 1959). Where these methods have been compared, the last has on the whole proved the most satisfactory (Garner., 1948; Lapins., 1959). Breakage records, particularly the evidence of natural breakage in one year old nursery trees, must be interpreted with care. In young trees union inevitably represents a point of mechanical weakness, especially during periods of rapid growth when lignification lags behind meri-stematic activity. This presently accounts for Chang's. (1937) view that the union represents a point of weakness 
in all trees. The anatomical structure of the union has been estimated macroscopically by recording the proportion of the cross sectional area exhibiting a smooth surface after forcible breakage. It has also been estimated by recording the proportion of vascular continuity of wood and bark in planed longitudinal sections of the union or on the trunk circumferences after removal of one or more sample bark strips across the union as a possible method of assessing union structure without destroying the tree. Herrero (1951) found that the most reliable microscopic indication of the onset of incompatibility in young trees the occurrence of breaks in cambial continuity after a continuous cambium had functioned for some time. In plums such breaks could usually be detected after the first season's growth, in pears on quince not until the second. Tissue distortion, although more prevalent in incompatible graft combinations, was not by itself a reliable diagnostic feature unless it persisted after second year. Some experience is necessary in the interpretation of microscope sections, since they only represent a very small proportion of the union, and some abnormalities can be caused by imperfect grafting techniques. In young bud-unions the lateral insertion of the bud also causes some inevitable tissue distortion as the scion develops, and it is therefore advisable to use longitudinal sections and to pay particular attention to the vascular connection at the base of the bud- shield which controls the subsequent development of a joint vascular cylinder.

The accuracy of forecasts based on an anatomical study of two year old unions was examined by Mosse (1958, 1960). On the whole there was a good correlation between the quality of unions in two and ten year old sample trees, but in the particular trees examined breakage under field conditions was rare. In plums it was related not only to quality of the union, but was also markedly influenced by variety.

Defective unions having the variety Victoria (which is itself brittle) as one graft component, were more liable to break than others equally defective. In a trail of the pear variety Williams on thirty different quince rootstocks Garner (1948) also observed that natural breakage, while relatively rare, occurred more frequently (up to 30 per cent) in some graft combinations, which judged on the smoothness of their breaking surface, were no worse than other combinations which did not break at all. Further investigation of this varietal effect might improve forecasting techniques.

\section{Determination techniques}

An early and accurate prediction of graft incompatibility has great importance because incompatible combinations could be avoided while compatible ones could be selected (Petkou et al., 2014). The involvement of certain enzymes in the cellular behavior during the first steps of graft formation has been studied in different species; although the specific role and effects on incompatibility is still not clear (Pina and Errea, 2005). The complexity of incompatibility and the mechanism behind the reactions have been investigated in several ways: in vitro pear and quince combinations (Moore, 1984), or between callus cultures of many different Prunus species, peroxidase activity and the production of phenolic compounds in Prunus (Rodrigues et al., 2001) and in pear-quince graftings (Musacchi et al., 2000) and the analysis of cyanogenic glycosides in some incompatible combinations. 
Table.1 Rootstock/scion compatibility performance in different Prunus species and some interspecific hybrids

\begin{tabular}{|c|c|c|c|}
\hline Rootstock type & Pedigree & Compatibility performance & References \\
\hline \multirow[t]{2}{*}{$\begin{array}{l}\text { Japanese } \\
\text { plum/peach }\end{array}$} & $\begin{array}{l}\text { Prunus salicinax } \\
\text { persica }\end{array}$ & $\begin{array}{l}\text { Very good with plums and } \\
\text { apricots, but not with peaches }\end{array}$ & Zaiger, 1982 \\
\hline & $\begin{array}{ll}\text { Prunus } & \text { cerasiferaand } \\
\text { interspecific } & \\
\text { hybrids } & \end{array}$ & $\begin{array}{l}\text { Performance differs } \\
\text { substantially depending } \\
\text { on the genotype, 'Adara' } \\
\text { rootstock confers compatibility } \\
\text { even with cherry cultivars } \\
\text { when it is used as an interstock }\end{array}$ & Zarrouket al., 2006 \\
\hline Peach & $\begin{array}{l}\text { Prunus persica } \times \text { Prunus } \\
\text { davidiana }\end{array}$ & $\begin{array}{l}\text { Wide range of compatibility } \\
\text { with most peachand nectarine } \\
\text { cultivars }\end{array}$ & $\begin{array}{l}\text { Lang and Ophardt, } \\
2000 \text {; } \\
\text { Zarrouk et al., } \\
2006\end{array}$ \\
\hline Peach/almond & Prunus persica $\times$ Prunus dulcis & $\begin{array}{l}\text { Wide range of compatibility } \\
\text { with most peach and nectarine } \\
\text { cultivars }\end{array}$ & $\begin{array}{l}\text { Lang and Ophardt, } \\
2000 \text {; } \\
\text { Zarrouk et al., } \\
2006\end{array}$ \\
\hline $\begin{array}{l}\text { Slow-growing } \\
\text { prunes }\end{array}$ & Prunus domestica & $\begin{array}{l}\text { Wide range of compatibility } \\
\text { with most peach and nectarine } \\
\text { cultivars }\end{array}$ & $\begin{array}{l}\text { Lang and Ophardt, } \\
\text { 2000; Zarrouk et } \\
\text { al., 2006 }\end{array}$ \\
\hline Cherry & $\begin{array}{l}\text { Prunus avium } \times \text { Prunus } \\
\text { pseudocerasus }\end{array}$ & $\begin{array}{l}\text { Wide range of compatibility } \\
\text { with most sweet cherry } \\
\text { cultivars except 'Sam' and } \\
\text { 'Van }\end{array}$ & $\begin{array}{l}\text { Rom and Carlson, } \\
1987\end{array}$ \\
\hline Cherry & Prunus avium & $\begin{array}{l}\text { Incompatible with peach, } \\
\text { nectarine and almond but } \\
\text { compatible with all sweet } \\
\text { cherry cultivars }\end{array}$ & $\begin{array}{l}\text { Beckman and } \\
\text { Lang, } 2003\end{array}$ \\
\hline Cherry & Prunus mahaleb & $\begin{array}{l}\text { Incompatible with several } \\
\text { sweet cheery } \\
\text { scion cultivars like 'Lapins', } \\
\text { 'Chelan' and Tieton }\end{array}$ & $\begin{array}{l}\text { Long and Kaiser, } \\
2010\end{array}$ \\
\hline Cherry & Prunus cerasus & $\begin{array}{l}\text { Incompatible with several } \\
\text { sweet cherry scion } \\
\text { Cultivars }\end{array}$ & $\begin{array}{l}\text { Long and Kaiser, } \\
2010\end{array}$ \\
\hline Cherry & $\begin{array}{l}\text { Prunus cerasus } \times \quad \text { Prunus } \\
\text { canescens }\end{array}$ & $\begin{array}{l}\text { Wide range of compatibility } \\
\text { with most sweet } \\
\text { cherry cultivars }\end{array}$ & $\begin{array}{l}\text { Long and Kaiser, } \\
2010\end{array}$ \\
\hline
\end{tabular}




\section{Formation of graft union}

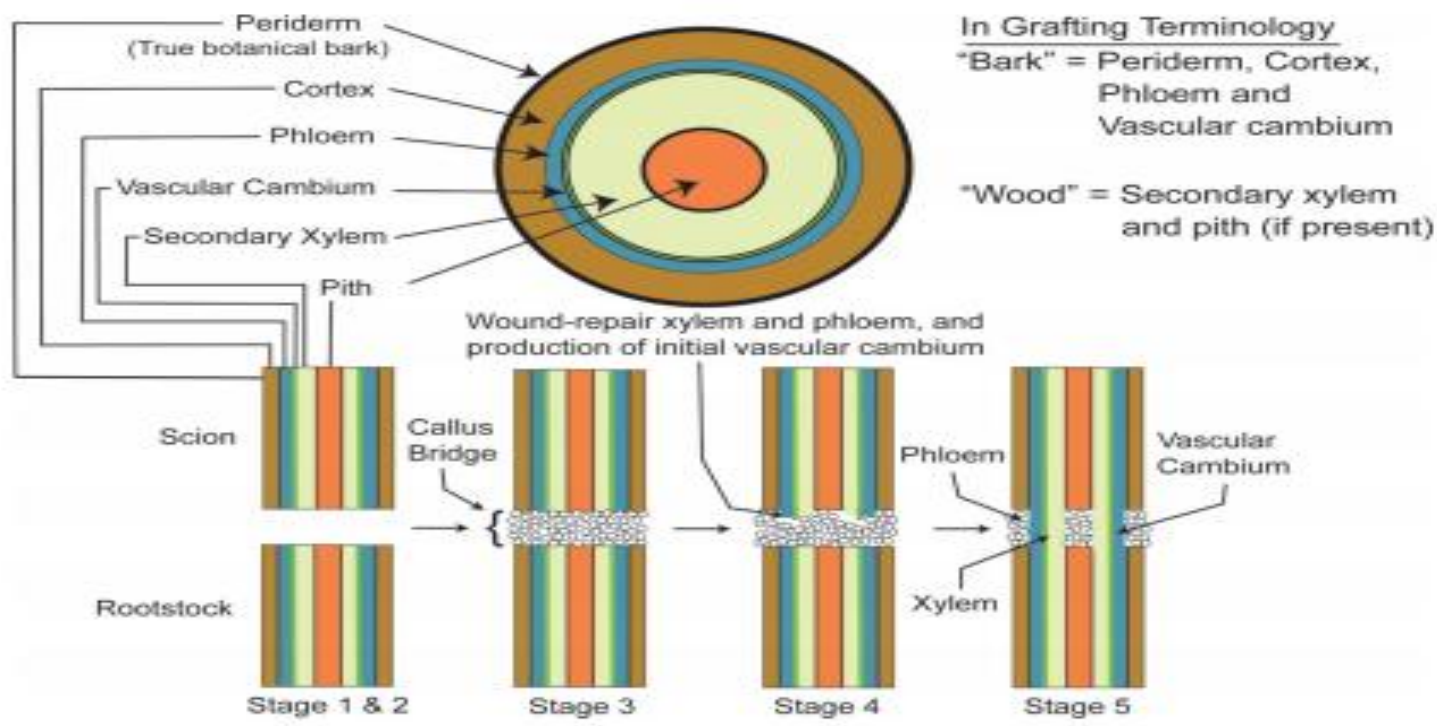

Source: Hartmann and Kester's Plant Propagation Principles and Practices.

Different methods for an early detection of graft incompatibility have already been used, like in vitro techniques (Errea et al., 2001), histological studies (Ermel et al., 1995 and 1999), isozyme analyses (Fernandez- Garcia et al., 2004 and Gulen et al., 2002) and phenol analyses (Musacchi et al., 2000).

\section{Electrophorosis method}

Isoforms of enzymes separated by electrophoresis were one of the earliest in vitro methods used for the prediction of graft incompatibility. (Santamour et al., 1986) reported that isoenzyme analysis of scions and rootstocks could be used to predict incompatibility before grafting in different cultivars. They stated that when stock and scions phenotype of peroxidase isoenzyme, the enzyme responsible for the polymerization of p-coumaryl alcohols to lignin (Quiroga et al., 2000) matched, grafting resulted in compatible union. In contrast, if isoenzyme phenotypes of graft partners were different, callus formation was impaired at the graft union (Santamour, 1988). Past research with other plant species showed that analysis of isoenzymes, especially peroxidases, and protein spectra between rootstock and scion before grafting could be used to predict intraspecific compatibility or incompatibility (Gulen et al., 2002); Fernandez- Garcia et al., 2004 and Pedersen, 2006).

Lachaund (1975) suggested that incompatibility could be avoided, to a certain extent, where similarity of protein composition between the partners would increase the probability of graft success. The comparison of protein profiles of graft combination between the partners would increase the probability of graft success. The comparison of protein profiles of graft incompatibility using SDS-PAGE was studied in Prunus species (Huang et al., 1984; Schmid and Feucht., 1985) and $V$. vinifera (Masa., 1985, 1986 and 1989). Poessel et al., (2006) showed by using proteome analysis of 
2D-PAGE analysis that some constituent proteins of leaves could be good candidates as compatibility markers. Researchers should keep in mind that grapes do not show immediate incompatibility, a situation more encountered between any other woody fruit crops such as pear and quince, and that grafting incompatibility between grapevine rootstock and scions may have resulted from virus at the graft union or even Agrobacterium infected material (May, 1994 and Creasap et al., 2004) or from a viral agent in the scion (Uyemoto and Rowhani, 2003).

\section{Phenol analysis}

The grafted partners often belong to the same species or genus but the use of genetically divergent genotypes is also common. In apricot (Prunus armeniaca) when is grafted on other Prunus species (especially in the inter-specific combinations), like peach (Lapins, 1959), plum and peach $\mathrm{x}$ almond (Cambra, 1986) graft incompatibility frequently occurs (Errea et al., 2001). The presence of phenols was generally associated with small cells in incompatible combinations, which did not form successful unions (Errea et al., 2001). The activity of IAA oxidase (Aloni, 1997) and transport of IAA transport (Stenlid, 1976) can be altered by naturally occurring substances such as phenols. Quantitative and qualitative differences in the phenol pattern between two graft partners can imply metabolic disfunctions at the graft union (Errea, 1998). Higher concentrations of catechin and epicatechin were found in the quince incompatible cultivars before the appearance of visible incompatibility symptoms (Musacchi et al., 2000). In less compatible apricot combination higher level of flavanols, catechin and epicatechin, was characteristics (Errea et al., 1992 and 2000). The theory that an accumulation of catechin above the graft union can be used as a biochemical marker of graft incompatibility (Musacchi et al., 2000). Phenol analysis is an applicable early sign for the prediction of graft incompatibility especially when new cultivars were used for different new cultivar rootstock combinations.

\section{X-ray tomography: future potential application}

The main interest of $\mathrm{X}$ - ray tomography method is associated with the image analysis; we present a no destructive 3D visualization of the graft interface that could provide new insights into the spatial tissue organization of the graft interface in grapevine. It was the first time, to the knowledge, that 3D imaging of the graft interface and vascular connections has been reported by Milien et al., (2012). This method could open new avenues to study graft quality assessment in woody plants.

The cellular events at the graft interface have been well characterized by histological studies in various woody plants, such as, Picea spp., apples and Prunus spp. (Soumelidou et al., 1994 and Olmstead et al., 2006). These histological studies (using light, confocal and electron microscopy) give beautiful and detailed images of the graft interface, but only in one plane.

Understanding spatial tissue organization between the two partners of a graft union is of paramount importance to management and selection of future rootstock genotypes as well as being of scientific interest. Till date graft union morphology has been studied with magnetic resonance imaging (MRI) in pine trees (Leszezynski et al., 2000) and grapevine (Bahar et al., 2010). Unfortunately, these MRI studies are of relatively low resolution and only present 2D virtual sections of the graft interface. Fluorescent dyes and 14Csucrose markers have been employed to characterize the functional developments of the phloem at the graft interface in tomato but 
the morphological characterization was also destructive and only provided 2D information (Schoning and Kollmann, 1997).

$\mathrm{X}$ - ray tomography is a minimally, invasive structural imaging method that allows 3D reconstruction of scanned objects (Larabell and Nugent, 2010). It has since been applied to the study of animals and minerals; the use of X- ray tomography began in plants in the late 1990s (Pierretet al., 1999). X- ray tomography has been applied to the study of the anatomy of stem wood samples of trees (Fromm et al., 2001; Steppe et al., 2004 and Longuetaud et al., 2005) and recently to the study of vessel dimensions and inter-vessel connections in grapevine (Brodersen et al., 2011). Other higher resolution tomography technologies also exist; these technologies can visualize and 3D reconstruct to the single cell level, but only in small plant samples such as seeds (Cloetens et al., 2006). Although graft incompatibility is rare in grapevine, grafting success can be very variable (May, 1994). After different tests and optimization of the scanning parameters, the method was applied to young vines with differing degrees of grafting success in order to understand how grapevine tissues and structures organize in response to the grafting. In the 3D organization of the graft interface in grapevine, could open new avenues to assess graft quality in woody plants.

The developmental process of the graft union attracted considerable attention and much information about it has been gathered. Several investigators have commented on the structural events that may be responsible for the development of cohesion between the stock and scion during graft ontogeny. These reports study cytological events occurring in response to grafting with special reference to possibility that the phenomena of cellular recognition could be involved in the development of functional vascular connections, since the basis of an incompatibility response could be determined by local interactions between the opposing cells of the graft union itself. When new rootstocks are bred and selected a number of traits need to be evaluated in addition to disease resistance such as their affinity and compatibility, vigour and adaptation to soils and climatic conditions. The mechanism of graft incompatibility is not fully understood. Researchers have studied how the union develops and functions over time and have studied how the union develops and functions over time and have confirmed that there is an incompatibility between different scion rootstock combinations. This incompatibility can be detected a few weeks after grafting by a poor vascular connection and phloem degeneration at the graft union. Despite the fact that callus formation can be considered as a common wound healing response in plants, recent advances in studying the plasmodesmata as the highly dynamic structures that offer pathway for symplastic cell communication, open the door to its important role in cell recognition, and compatibility and incompatibility response. This review will focus on the knowledge currently available on the metabolic response during the formation and determination techniques of the stock/scion graft union in order to help the effort for identify future metabolic markers to be used in breeding programs.

\section{References}

Aloni, B. 1987. Differentiation of vascular tissues. Ann. Rev. Plant Physiol., 38: 179-204.

Aloni, B., Karni, L., Deveturero, G., Levin, Z., Cohen, R., Kazir, N. et al., 2008. Physiological and biochemical changes at the rootstock-scion interface in graft combinations between Cucurbita rootstocks and melon scion. J. Horti. Sci. Biotech. 83: 777-783.

Aloni, R. 1995. The induction of vascular tissues 
by auxin and cytokinin. In P.J. Davies (ed.) Plant hormones. Kluwer Academic Publishers. Dordrecht. The Netherlands.p.531-546.

Aloni, R. 2001. Foliar and axial aspects of vascular differentiation hypothesis and evidence. Journal of plant growth Regulation.20:22-24.

Aloni, R. 2010. The induction of vascular tissues by auxin plant hormones. In P.J. Davies (ed.) Springer, Dordrecht, The Netherlands. p. 485-518.

Bahar, E., Korkutal, L., Carbonneau, A. and Akcay, G. 2010. Using magnetic resonance Imaging technique (MRI) to investigate graft connection and its relation to reddening discolouration in grape leaves. J. Food Agric. Environ., 8:293-297.

Beckman, T.G., and G.A. Lang. 2003.Rootstock breeding for stonefruits. ActaHorti. 622:531-551

Bradford, F.C., and Sitton, B.G. 1929. Defective graft unions in the the apple and the pear. Tech. Bull. Mich. Agric. Exp. Stat., 99.

Braun, H. J. 1958. Die normalen Verwachsungsvorgangenach Pfropfung von Laubbaumen. Z.Bot., 46: 309-338.

Brodersen, C.R., Lee, E.F., Choat, B., Jansen, S., Phillips, R.J., Shackel, K.A., McElrone, A.J and Matthews, M.A. 2011. Automated analysis of three dimensional xylem networks using high resolution computed tomography. New Phytol., 191: 1168-1179.

Buchloh, G. 1958. Verwachsung and Verwachsungsstorungalsvarietaten and Cydoniaoblonga. Habilitationsschrift Landw, FakultatWilhelms - Universitat, Bonn.

Cambra, R. 1986. Compatibilidad de variedades de albaricoquero (Prunsaemeniaca L.) con hibridos de almendromelocotonero (Prunus amygdalo- persica (west) Rehd. An.Aula Dei.,18 (1-2) ; 87-90.

Chang, Wen- Tsai. 1937. Studies in incompatibility between stock and scion, with special reference to certain deciduous fruit trees. J. Pomol., 15: 267-325.

Cloetens, P., Mache, R., Schlenker, M. and LerbsMache, S. 2006. Quantitative phase tomography of Arabidopsis seeds reveals intercellular void network. PNAS, 103;
14626-14630.

Creasap, J.E.,REID, C.L.,Goffinet, M.C. and Burr, T.J. 2004. Effect of Agrobacterium vitis strain $\mathrm{Ff} 2 / 5$ on graft compatibilin in Vitis spp. Am. J. Enol. Viticult., 55:4.

Eames, A. J., and Cox, L. G. 1945. A remarkable tree-fall and an unusual type of graft union failure. Amer. J. Bot., 32: 331-335.

Ermel, F.F., Catesson, A.M. and Poessel, J.L. 1995. Early histological diagnosis of apricot/peach $\mathrm{x}$ almond graft incompatibility: statistical analysis of data from 5 month old grafts. Acta Hort., 384: $497-503$.

Ermel, F.F., Kervella, J., Catesson, A.M and Poessel, J.L. 1999. Localized graft incompatibility in pear/ quince (Pyrus communis/ Cydoniaoblonga) combinations: multivariate analysis of histological data from 5 month old grafts. Tree Physiol., 19 (10): 645-654.

Errea, P. 1998. Implications of phenolic compounds in graft incompatibility in fruit tree species. Sci. Hort., 74:195-205.

Errea, P., Felipe, A., Herrero, M. 1994.Graft establishment between compatible and incompatible Prunus spp. J. Exp. Bot. 45: 393-401.

Errea, P., Garay, L. and Marin. J.A.2001. Early detection of graft incompatibility in apricot (Prunus armeniaca) using in vitro techniques. Physiologia Plantarum, 112: 135-141.

Errea, P., Treutter, D. and Feucht, W. 1992. Specificity of individual flavan-3-ols interfering with the grafting stress of apricots. Angewandte Botanik, 66: 21-24.

Evans, W D., and Hilton, R. J. 1957. Methods of evaluating stock/scion compatibility in apple trees. Canad. J. Plant Sci., 37: 327336.

Fernandez- Garcia, N., Carvajal, M. and Olmos, E. 2004. Graft union formation in tomato plants: peroxidase and catalase involvement. Ann. Bot., 93(1): $53-60$.

Feucht, W., Treutter, D., and Schmid, P. 1988. Inhibition of growth and xylogenesis and promotion of vacuolation in Prunus callus by the flavanone pruning. Plant Cell Report.7: 1898-1192.

Fromm, J.H., Sautter, L., Matthies, D., Kremer, J., 
Schumacher, P. and Ganter, C. 2001.Xylem water content and wood density in spruce and oak trees detected by high- resolution computed tomography. Plant Physiol., 127:416 - 425 .

Garner, R. J. 1944. Double -working and bridging incompatible combinations of pear and quince. Rep. E.Malling Res. Stat. for 1943, A27: 80- 85 .

Garner, R. J. 1948. The nursery behavior of the Williams Bon Chretien pear when worked upon a wide range of Quince rootstocks. Rep. E. Malling Res. Stat. for 1947, A31: 65-70.

Garner, R. J. 1953. Doubling working pears at budding time.Rep. E. Malling Res. Stat. for 1952, A36: 174-175.

Garner, R. J. 1958. The grafter's Handbook. ( $2^{\text {nd }}$ shift). Faber \& Faber, London.

Garner, R. J. and Nicoll, C. P. 1957. Observations on Prunus cerasus, P. mahaleb and other species as rootstocks for sweet cherries. Rep. E. Malling Res. Stat. for 1956, A40: 63-72.

Gulen, H., Arora, R., Kuden, A., Krebs, S.L. and Postman, J.2002. Peroxidase isozyme profiles in compatible and incompatible pear-quince graft combinations. J. Am. Soc. Hort. Sci., 127 (2): 152 -157.

Hartmann, H.T., Kester, D.E., Davies, F.T., Geneve, R.L., 2002. Plant Propagation. Principles and Practices seventh ed. Prentice Hall, Upper Saddle River, NJ, 849 pp. ISBN 0-13-679235- 679239.

Hatton, R.G. 1935. Rootstocks for pears.Rep. E. Malling Res. Stat. for 1934, A18: 75-86.

Herrero, J. 1951. Studies of compatible and incompatible graft combinations with special references to hardy fruit trees. J. hort. Sci., 26: 186-237.

Herrero, J. 1955. Incompatibilidad entre patron e injerto. I. Comportamiento de algunas combinations reciprocas. An. Aula Dei, 4: 149-166.

Huang, F.H., Tasai, S. and Rom, R.C. 1984. An electrophoresis method for water soluble protein of Prunus. Hort. Sci., 19: 242-243.

Jefree. C.E., Yeoman, M.M., 1983. Development of intercellular connections between opposing cells in graft union. New Phytol.93: 491-509.
Koepke, T., and Dhingra, A. 2013. Rootstock scion somatogenetic interactions in perennial composite plants. Plant Cell Report.32: 1321-1337.

Kollmann, R., Glockmann, C., 1985. Studies on graft unions. I. Plasmodesmata between cells of plants belonging to different unrelated taxa. Protoplasma124: 224-235.

Kollmann, R., Yang. S., Glockmann, C., 1985. Studies on graft on graft unions. II. Continuous and half plasmodesmata in different regions of the graft interface. Protoplasma 126: 19-29.

Lachaund, S. 1975. Incompatibility. Des greffesetvieillissement chez les vegetaux. II. Incompatibility. des greffes et ses rapports avec levieillissement. Ann. Biol., $14 ; 97-128$

Lang, G.A., and D. Ophardt. 2000. Intensive crop regulationstrategies in sweet cherries. Acta Horti.514:227-234.

Lapins, K. 1959. Some symptoms of stock-scion incompatibility of apricot verities on peach seedling rootstock. Can. J. Plant Sci., 39: $194-203$.

Larabell, C.A and Nngent, K.A. 2010.Imaging cellular architecture with $\mathrm{X}$ rays.Curr.Opin. Struct.Bio.,20: 623 -631.

Lee, J.M., and Oda, M. 2003. Grafting of herbaceous vegetable and ornamental crops. Horti. Reviews. 28:61-124.

Leszczynski, R., Byczkowski, B., Jurga, S. and Korszun, S. 2000. NMR microimaging studies of the union between stock and scion. Appl. Magn. Reson., 18: 147-153.

Long, L.E., and C. Kaiser. 2010. Sweet cherry rootstocks. Pacific Northwest Extension 619:8.

Longuetaud, F., Saint-Andre, L. and Leban, J.M. 2005. Automatic detection of annual growth units on Piceaabies logs using optical and $\mathrm{X}$ - ray techniques. J. Non destruct. Eval., 24: 29-43.

Lucas, W.J., Ding, B., Van der Schoot, C., 1993.Plasmodesmata and supracellular nature of plants. New Phytol.125: 435-476.

Masa, A. 1985. Biochemical method for determination of scion- rootstock affinity in grape. Vitis, 24: 12-16 (Spanish, abstr. English).

Masa, A. 1986. Study on the isoenzymatic 
structure of several enzymes of Vitis vinifera cvs and of rootstocks. Application for the biochemical determination of scionrootstock affinity. Connaissance de la vigneet du vin, 20 (1): 1-16 (French, abstr. English).

Masa, A. 1989. Biochemical affinity between the Vitis vinifera L.cv. ALBARINO and several rootstocks. Connaissance de la vigneet du vin, 23 (4): 207 - 214 (French, abstr. English).

Mattsson, J., Ckurshumova, W., and Berleth, T. 2003.Auxin signaling in Arabidopsis leaf vascular development. Plant Physi.131:1327-1339.

May, P. 1994.Using grapevine rootstocks: The Australian perspective. Winetitles, Cowandilla, Australia, 62 p.

Mendel, K. 1936. The anatomy and histology of the bud union in citrus. Palest. J. Bot. hort. Sci., 1(2): 13-46.

Miller, P.W., Rawlings, C. O., and Painter, J. H. 1957.Blackline of Persian walnut. $48^{\text {th }}$ A. R. north. Nut Grs Ass., pp. 32-33.

Moing, A., Carde, J.P., 1988. Growth, cambial activity and phloem structure in compatible and incompatible plum grafts. Tree Physiol. 4(4), 347-359.

Moore, R. 1984. A model for graft compatibilityincompatibility in higher plants. Am. J. Bot., 71: 751-758.

Mosse, B. 1960. Graft incompatibility in plums: Observations on a ten-year-old field trial. J.hort.Sci., 35: $275-265$.

Musacchi, S., Masia, A. and Fachinello, J. 2000. Variation of some enzymatic activities in relationship to scion/stock compatibility in pear/quince combinations. Acta Hort., 596: 389-392.

Olmstead, M.A., Lang, N.S., Ewers, F.W. and Owens, S.A. 2006. Xylem vessel anatomy of sweet cherries grafted onto dwarfing and non- dwarfing rootstocks. J.Am.Soc. Hort. Sci., 131: 577-585.

Parham, R.A., and Kaustinen. 1977. On the site of tannin synthesis in the plant cells. Bot. Gazzette, 138:465-467.

Pedersen, B.H. 2006. Determination of graft compatibility in sweet cherry by a coculture method. J. Hort. Sci. Biotechnol., 81: 759- 764 .
Petkou, D., Diamantidis, G. and Vassilakakis, M. 2004. Anionic peroxidase isoform profiles from calli and barks of pear cultivars and quince rootstock. Em. J. Biol. Res., 2: 5155.

Pierret, A., Capowiez, Y., Moran, C.J. and Kretzschmar, A. 1999. X- ray computed tomography to quantify tree rooting spatial distributions. Geoderma, 90: 307-326.

Pina, A. and Errea, P. 2005. A review of new advances in mechanism of graft compatibility-incompatibility. Sci. Hort., 106: 1-11.

Poessel, J.L., Faurobert, M., Loonis, M., Corre, M.N., Olivier, G., Restier, V., Audergon, J.M. and Masse, M. 2006. Physiological and genetic studies on apricot/prunus rootstocks graft compatibility. In: ISHA Acta Horticulture, 701: XII International symposium on apricot culture and decline.

Proebsting, E. L. 1928. Further observations on structural defects of the graft union. Bot. Gaz., 86: 82-92.

Quiroga, M., Guerrero, C., Botella, M.A., Barcelo, A., Amaya. I., Medina, M.I., Alonoso, F.J., deForchetti, S.M., Tigier, H. and Valpuesta, V. 2000. A tomato peroxidase involved in the synthesis of lignin and suberin. Plant Physiol., 122: 1119 - 1127.

Randhawa, G. S., and Upshall, W.H. 1949. Congeniality of some pear varieties on Quince. A. Sci. Agric., 29: 490- 493.

Roberts, R. H. 1949. Theoretical aspects of graftage.Bot. Rev., 15:423-163.

Rodrigues, A.C., Machado, L.B., Diniz, A.C., Fachinello, J.C. and de Luces Fortes, G.R. 2001. Evaluation of graft compatibility in Prunus sp. Rev. Bras.Frutic., 23(2): 455464.

Rom, R.C., and R.F. Carlson. 1987. Rootstocks for fruit crops.Wiley, New York, USA.

Salvatierra, M.A., Gemma, H., and Iwahori.S. 1999. Histochemical observation and HPLC analysis of phenolic compounds at the graft union dwarf peach trees grafted onto Prunus tomentosa. J. Jap. Soc. Horti. Sci. 68: 724-733.

Santamour Jr., F.S., McArdle, A.J. and Jaynes, R.A. 1986. Cambial iso- peroxidase isoenzymes inchinese chestnut.J.Environ. 
Hort., 6:33 -39.

Santamour Jr., F.S., McArdle, A.J. and Jaynes, R.A. 1988. Cambial peroxidase enzymes related to graft incompatibility in red oak. J. Environ. Hort., 6: 87-93.

Scaramuzzi, F. 1957. La diversa influenza delleradici e delsoggettosullosviluppo del pero "Kaiser" innestatisucotogno. Riv. Ortoflorofrutic, itali., 41: 258- 268.

Schmid, P.PS. and Feucht, W.1985. Compatibility in Prunus avium/Prunuscerasusgraftings during the initial phase. III. Isoelectrofocusing of proteins, peroxidases and acid phosphatases during union formation. J. Hort. Sci.60:311-318.

Schoning, U. and Kollmann, R. 1997. Phloem translocation in regenerating in vitro heterografts of different compatibility. J.Exp. Bot., 48: 289-295.

Schulz, A. 1999.Physiological control of plasmodesmalgating. In: van Bel, A.J.E., van Kesteren, W.J.P. (Eds.). Plasmodesmata: Structure, Function, Role in Cell Communication. Springer Verlag, Berlin, Heidelberg, New York, pp. 173204.

Shimomura. T., and Fujihara, K. 1977. Physiological study of graft union formation in Cactus. II. Role of auxin on vascular connection between stock and scion. Internat. Jap. Soc. Horti. Sci. 45:397406.

Sorce, C., Massai, R., Picciarelli, P., and Lorenzi, R. 2002. Hormonal relationships in xylem sap of grafted and ungrafted Prunus rootstocks. Sci. Horti. 93:333-342.

Soumelidou, K., Battey, N.H., John, P. and Barnett, J.R. 1994.The anatomy of the developing bud union and its relationship to dwarfing in apple. Ann. Bot., 74: 605-611.

Stafford, H.A. 1990. Flavonoid metabolism.CRC
Press. Boca Raton, Florida, USA.

Stenlid, G. 1976. Effects of flavonoids on the polar transport of auxins. Physiol.Plant., 38: 262-266.

Steppe, K., Cnudde, V., Girard, C., Lemeur, R., Cnudde, J.P. and Jacobs, P. 2004. Use of Xray computed microtomography for noninvasive determination of wood anatomical characteristics. Struct. Biol., 148: 11-21.

Thiel, K. 1954. UntersuchungenzurFrage der UnvertraglichkeitbeiBirnedelsorten auf Quitte A (Cydonia E.M A).Gartenbauwiss., 1(19): 127-159.

Tiedemann, R. 1989. Graft union development and symplastic phloem contact in the heterograft Cucumissativus on Curcubitaficifolia. J. Plant Physiol. 134: 427-440.

Treutter, D., and Feucht, W. 1991. Accumulation of phenolic compounds above graft union of cherry trees. Gartenbauwissenschaft.56: 134-137.

Uyemoto, J.K. and Rowhani, A. 2003. Discovery of different grapevine sources with graft transmissible agents causing unionincompatibility on sensitive rootstocks. In: Proceedings of the international council for the study of viruses and virus.

Weatherhead, I.1986. Causes of graft failure in Sitka spruce (Piceasitchensis- Bomg.Carr.). Ph.D. thesis, University of Reading.

Zaiger, C.F. 1982. Interspecific rootstock tree 4G-816. In Patent A01H 5/03, USA.p.3.

Zarrouk, O., Gogorcena, Y., Moreno, M.A. and Pinochet. J. 2006.Graft compatibility between peach cultivars and Prunus rootstocks. Amer. Soci. Horti. Sci. 41:13891394.

\section{How to cite this article:}

Komal Dogra, Kiran Kour, Rakesh Kumar, Parshant Bakshi and Vijay Kumar. 2018. GraftIncompatibility in Horticultural Crops. Int.J.Curr.Microbiol.App.Sci. 7(02): 1805-1820. doi: https://doi.org/10.20546/ijcmas.2018.702.218 